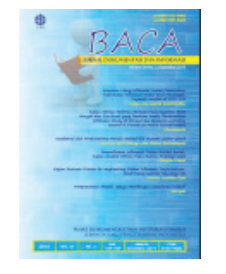

\title{
PENGALAMAN E-LEARNING SECARA PENUH: PENGGUNAAN EDMODO DALAM KELAS VIRTUAL
}

\author{
Arief Wicaksono \\ Magister Departemen Ilmu Perpustakaan dan Informasi, Universitas Indonesia \\ Korespondensi: arief.wicaksono41@ui.ac.id
}

Diajukan: 29 Maret 2016; Direview: 18 November 2016; Diterima: 24 Maret 2017; Direvisi: 28 Maret 2017

\begin{abstract}
E-learning in full design is believed to be a solution in a digital society. The reality is not entirely correct for granted. This study examines the experience of e-learning in full design at the graduate program the Department of Library and Information Science, University of Indonesia that works for half semester on a single subject. The research method used qualitative research. Data collected by online interviews and online observation. The results showed that virtual classroom using Edmodo proven to increase student participation. However, in practice the advantages of e-learning can backfire for students. The extreme point of the participation in a virtual classroom is done minimally and only to abort obligations.
\end{abstract}

\begin{abstract}
ABSTRAK
Pembelajaran online secara penuh dipercaya dapat menjadi solusi bagi masyarakat digital. Kenyataannya tidak sepenuhnya dapat berjalan dengan mulus. Penelitian ini mengkaji pengalaman e-learning secara penuh di lingkungan program magister Departemen Ilmu Perpustakaan dan Informasi, Universitas Indonesia selama setengah semester pada satu mata kuliah. Metode penelitian yang digunakan adalah kualitatif dengan menggunakan alat pengumpul data berupa wawancara online dan observasi online. Hasilnya menunjukkan bahwa kelas virtual menggunakan Edmodo dapat meningkatkan partisipasi mahasiswa. Namun dalam prakteknya keunggulan dari e-learning sendiri dapat menjadi bumerang bagi mahasiswa. Titik ekstrimnya partisipasi dalam kelas virtual dilakukan secara minimal dan hanya untuk menggugurkan kewajiban.
\end{abstract}

Keywords: E-learning; Virtual classroom; Edmodo; Library and information science

\section{PENDAHULUAN}

Pendahuluan merupakan latar belakang penelitian dan permasalahan penelitian termasuk di dalamnya pertanyaan penelitian. Permasalahan serta pertanyaan penelitian berangkat dari latar belakang yang dikemukakan. Mata kuliah AB merupakan salah satu mata kuliah Program Magister Departemen Ilmu Perpustakaan dan Informasi Universitas Indonesia. Pengajar mata kuliah ini adalah Dosen A dan Dosen B. Dosen A mengajar dari awal semester hingga tengah semester dengan menggunakan metode pengajaran tatap muka dalam kelas konvensional. Dosen B mengajar setengah semester berikutnya menggunakan metode e-learning dalam kelas virtual dengan menggunakan aplikasi Edmodo. Dosen B menyatakan dalam Edmodo "...kita tidak ber-KBM (kegiatan belajar mengajar) dengan tatap muka di kelas secara fisik”. Dosen B menerapkan konsep e-learning secara penuh tanpa menggunakan kelas konvensional. Edmodo menjadi kelas virtual di mana seluruh aktivitas dan komunikasi belajar mengajar dilakukan dalam Edmodo. Dosen B berkeinginan memberikan pengalaman kepada mahasiswanya pada proses e-learning secara penuh, yaitu merasakan secara praktek langsung bagaimana proses belajar mengajar tanpa ada pertemuan fisik. 
E-learning dalam praktek dapat dilakukan secara penuh maupun tidak penuh seluruhnya (Gedera, 2014). E-learning secara penuh merupakan proses belajar mengajar tanpa ada pertemuan fisik sedikit pun dalam kelas konvensional. Seluruh proses dilakukan melalui kelas virtual. Sementara pada e-learning secara tidak penuh, proses belajar mengajar jarak jauh dicampur dengan beberapa kali pertemuan fisik. Perbedaan atau batasan kedua e-learning ini, yaitu pada ada atau tidaknya pertemuan fisik. Aplikasi e-learning, misalnya Edmodo, pada e-learning secara tidak penuh bersifat bukan kelas virtual karena hanya digunakan untuk menaruh bahan pengajaran, mengumpulkan tugas, atau aktivitas lainnya yang hanya bersifat administrasi. Sementara Edmodo pada e-learning secara penuh menjadi kelas virtual karena tidak hanya bersifat administrasi tetapi berupa proses belajar mengajar, seperti diskusi, presentasi, pertanyaan, komentar, dan sebagainya.

Sebelum pengajaran dimulai, ketua dari kelas mata kuliah AB dipanggil untuk bertemu dengan Dosen B. Dalam pertemuan tersebut, ketua kelas diminta menyampaikan kepada mahasiswa yang mengikuti mata kuliah $\mathrm{AB}$ untuk mendaftarkan diri ke aplikasi Edmodo dan bergabung dalam kelas virtual yang sudah dibuat oleh Dosen B. Awal interaksi adalah perkenalan diri masing-masing mahasiswa. Perkenalan diri dilakukan dalam kelas virtual. Perkenalan dimulai dengan pemilihan foto dalam akun pribadi masing-masing dan dilanjutkan dengan mem-posting kalimat perkenalan dalam kelas virtual.

Selanjutnya Dosen B memberikan tugas bahasan untuk dibahas dalam lima kelompok diskusi. Masing-masing kelompok diberikan satu bahan bacaan, kemudian secara bergiliran dipresentasikan secara online. Kelompok yang sedang tidak mendapat giliran untuk mempresentasikan diminta untuk memberikan tanggapan dan pertanyaan. Tanggapan dan pertanyaan tersebut akan ditanggapi dan dijawab oleh kelompok yang presentasi. Layaknya kelas tatap muka, masing-masing mahasiswa diharapkan aktif dalam berdiskusi.

Setelah seluruh kelompok sudah melakukan presentasi, Dosen B memberikan tugas akhir berupa penulisan esai. "Buatlah makalah yang merupakan karangan singkat/esai dengan topik besar... pembahasannya bukan menyangkut hal teknis atau prosedural, tetapi pemikiran kritis Anda, khususnya menyangkat aspek-aspek yang biasanya luput atau terlupakan dalam persoalan besar...". Dengan demikian, selama setengah semester pengajaran dilakukan secara virtual. Tidak ada pertemuan fisik berupa kelas tatap muka, e-learning dilakukan secara penuh.

Kelas virtual dalam penelitian ini merupakan suatu ruang tempat belajar mengajar yang bersifat virtual. Ruang kelas dalam mata kuliah $\mathrm{AB}$ diciptakan melalui Edmodo yang merupakan aplikasi kelas online yang tidak berbayar. Setiap mahasiswa dapat memberikan persepsi atau mengintepretasikan realitas yang telah dialaminya ketika menjalani e-learning secara penuh dengan menggunakan Edmodo sebagai kelas virtual. Proses belajar mengajar yang dijalani oleh mahasiswa juga dapat berbeda antara satu dengan lainnya. Persepsi dan proses yang berbeda disebabkan berbagai faktor, seperti budaya, pengetahuan, dan pengalaman masing-masing mahasiswa.

Latar belakang di atas menjelaskan kemungkinan masalah, seperti terdapat persepsi yang berbeda atas realitas dan pengalaman yang telah dirasakan mahasiswa ketika menjalani e-learning secara penuh dengan menggunakan Edmodo sebagai kelas virtual. Proses menjalani e-learning secara penuh juga mungkin berbeda. Perbedaan persepsi dan proses menjalani ini berangkat dari budaya, pengetahuan, dan pengalaman dari masing-masing mahasiswa. Fokus masalah penelitian ini adalah persepsi mahasiswa atas e-learning secara penuh dengan menggunakan Edmodo sebagai kelas virtual. Adapun pertanyaan penelitian ini, yaitu: (a) 
apakah pengalaman telah menggunakan aplikasi e-learning sebelum mengikuti mata kuliah $\mathrm{AB}$ mempunyai pengaruh dalam mengikuti e-learning secara penuh dalam kelas virtual pada mata kuliah AB?; (b) bagaimana persepsi mahasiswa atas kelebihan dan kekurangan e-learning secara penuh dalam kelas virtual pada mata kuliah AB?; dan (c) bagaimana proses belajar mengajar yang terjadi pada e-learning secara penuh dalam kelas virtual pada mata kuliah AB? Berdasarkan permasalahan tersebut, tujuan yang ingin dicapai penelitian ini adalah membangun pemahaman mendalam atas berjalannya e-learning secara penuh dalam kelas virtual pada mata kuliah $\mathrm{AB}$.

\section{TINJAUAN PUSTAKA}

Tinjauan pustaka difokuskan pada penjelasan atas e-learning dan pembagian dari e-learning yang dapat diselenggarakan secara penuh maupun tidak penuh. Aplikasi Edmodo yang digunakan untuk kelas virtual juga akan dijelaskan. Dua penelitian di Indonesia yang mengkaji e-learning yang menggunakan Edmodo dipaparkan dalam rangka mendapatkan gambaran penelitian yang sudah ada sebelumnya dan juga untuk menjelaskan perbedaan penelitian ini dari penelitian sebelumnya.

\subsection{E-Learning}

Pada kajian ini digunakan istilah e-learning. Namun sehari-hari terdapat berbagai istilah yang merujuk pada konsep yang sama dengan e-learning, misalnya pembelajaran online (online learning), pembelajaran jarak jauh (distance learning), dan pembelajaran digital (digital learning). E-learning adalah "the use of educational technologies to design, deliver, and manage both formal and informal learning and knowledge sharing at any time, any pace and any place (Gedera, 2014)". Jika diterjemahkan secara bebas, e-learning merupakan penggunaan teknologi dalam mendesain, menyampaikan, dan mengelola pembelajaran formal dan informal dan sharing pengetahuan kapan saja dan di mana saja. Menurut Hogan (2011), e-learning adalah "a methods of teaching at a distance via the internet". Jadi, e-learning merupakan metode pengajaran jarak jauh dengan bantuan internet. Dari definisi tersebut dapat disimpulkan bahwa e-learning adalah metode pembelajaran jarak jauh baik formal dan informal dengan menggunakan teknologi informasi dan komukasi (TIK) termasuk internet yang memungkinkan terjadinya sharing pengetahuan yang dapat dilakukan kapan saja dan di mana saja.

Dalam pengajaran, e-learning dapat digunakan secara penuh tanpa adanya interaksi tatap muka, namun ada juga yang menggunakan e-learning sekaligus pengajaran tatap muka (Gedera, 2014). E-learning secara penuh merupakan pembelajaran yang dilakukan benar-benar dalam kelas virtual. Seluruh interaksi dari awal sampai akhir pembelajaran dilakukan melalui kelas virtual. Sementara e-learning yang dicampur dengan interaksi tatap muka adalah pembelajaran yang dilakukan dengan menggunakan kelas tatap muka dan kelas virtual. Porsi antara kelas virtual dan kelas tatap muka dapat sama banyak atau lebih banyak salah satunya. Hal ini seperti komunitas online yang juga melakukan pertemuan fisik di suatu titik waktu dalam interaksinya. Hogan (2011) menambahkan satu lagi penggunaan e-learning, yaitu e-learning hanya menjadi tambahan dalam instruksi kelas. Artinya, e-learning hanya berfungsi sebagai tambahan saja dalam interaksi pengajaran tatap muka. E-learning di posisi ini berjalan secara beriringan dengan kelas tatap muka secara langsung sebagai contoh dosen yang 
mengunggah bahan melalui media e-learning dalam kelas tatap muka.

\subsection{Edmodo}

Edmodo merupakan salah satu aplikasi kelas online yang bersifat gratis. Edmodo didirikan di Chicago, Illinois. Edmodo diciptakan untuk membawa pendidikan kepada lingkungan abad ke-21. Tujuan Edmodo yaitu menciptakan jaringan pembelajaran global yang tidak terbatas pada sekat negara dan didedikasikan menghubungkan seluruh pembelajar dengan individu dan sumber daya yang mereka butuhkan untuk mencapai potensi penuhnya. Aplikasi Edmodo dapat menyatukan tiga komponen, yaitu pengajar, yang diajar, dan orang tua, dalam pengajaran dan pendidikan dalam satu ruang virtual. Pengajar dapat menciptakan kelas yang blended, bergabung dengan komunitas pembelajaran global, dan menemukan dan membagi sumber yang bernilai. Untuk orang tua dapat memantau pekerjaan rumah anaknya, membaca dan mereview pengajaran yang dilakukan, melihat pengajaran, kuis, dan skema pembelajaran secara langsung. Fitur-fitur yang terdapat pada Edmodo sangat mudah digunakan, mulai dari membuat avatar atau foto untuk profil, melakukan posting baik ke kelas, kelompok kecil dalam kelas, mengunggah bahan, membaginya kepada kelas, mengirimkan pesan secara langsung kepada peserta lain dalam kelas maupun ke pengajar dan mengunggah tugas. Edmodo juga dapat diunduh dan digunakan di ponsel pintar yang menggunakan sistem operasi Microsoft, Android, dan Mac.

\subsection{Penelitian Terdahulu}

Marzal (2014) melakukan penelitian penggunaan Edmodo sebagai media e-learning. Sebanyak 94 mahasiswa tahun pertama program studi pendidikan matematika Fakultas Keguruan dan Ilmu Pendidikan (FKIP) Universitas Jambi diminta melakukan perkuliahan secara virtual menggunakan aplikasi Edmodo selama satu semester. Seluruh mahasiswa tersebut belum pernah menggunakan aplikasi Edmodo. Hasil penelitiannya adalah mahasiswa dapat mengikuti perkuliahan e-learning melalui aplikasi Edmodo dengan baik mulai dari mahasiswa yang tergabung dalam grup, menyerahkan tugas, dan mengikuti kuis. Mahasiswa tidak mengalami kesulitan yang berarti dalam masalah teknis penggunaan Edmodo. Persepsi mahasiswa terhadap aspek teknis Edmodo berada pada kecenderungan level setuju, kecuali pada aspek dapat pindah halaman dengan cepat, menyukai voting dengan Edmodo, kelas online Edmodo mudah, download dan upload file dengan mudah pada Edmodo. Pada aspek tersebut, kecenderungan levelnya adalah netral.

Sementara persepsi mahasiswa terhadap fitur Edmodo berada pada kecenderungan level netral. Walaupun menyatakan netral, secara statistik rata-rata persetujuan mereka di atas pernyataan netral. Lalu pada fitur suka menggunakan Edmodo, suka dengan warna dan tampilan Edmodo, dan suka folder/library yang ada di Edmodo kecenderungan level mahasiswa pada setuju. Menurut Marzal, kondisi persepsi pada fitur Edmodo ini tidak terlalu tinggi dapat disebabkan oleh masa penggunaan Edmodo yang relatif singkat. Dalam kesimpulan akhir, dinyatakan bahwa mahasiswa mempunyai persepsi positif terhadap Edmodo.

Penelitian lain dilakukan oleh Asmuni dan Hidayati (2015) yang mengkaji pengaruh penggunaan Edmodo terhadap partisipasi mahasiswa dalam diksusi kelas. Penelitian ini dilakukan melalui eksperiman dengan desain faktorial untuk menentukan 
efek dari perlakuan dua variabel independen terhadap dua variabel dependen. Penelitian dilaksanakan di Sekolah Tinggi Keguruan dan Ilmu Pendidikan Persatuan Guru Republik Indonesia (STKIP PGRI) Jombang, Jawa Timur, Indonesia. Dalam penelitian populasi dikelompokkan ke dalam 4 kelas pararel dan diperlakukan sama, yaitu diterapkan diskusi kelompok kecil di luar jam perkuliahan, dan presentasi dalam diskusi kelas, serta diskusi umum (semua kelas) dalam Edmodo di luar jam perkuliahan sebagai perkuliahan mandiri. Karena bersifat mandiri, maka diskusi umum dalam Edmodo hanya diikuti sebagian dari populasi (89 mahasiswa). Hasil penelitiannya yaitu: (1) terdapat pengaruh yang signifikan penggunaan Edmodo terhadap partisipasi mahasiswa dalam diskusi kelas pada materi ajar teoritis maupun praktis; (2) terdapat hubungan yang signifikan antara penggunaan Edmodo dengan partisipasi mahasiswa dalam kelas materi ajar teoritis, dan (3) terdapat hubungan yang signifikan antara penggunaan Edmodo dengan partisipasi mahasiswa dalam kelas materi ajar praktis.

Perbedaan kedua penelitian ini adalah terletak pada penggunaan media e-learning. Pada Marzal, e-learning digunakan secara penuh selama satu semester. Sementara pada Asmuni dan Hidayati, e-learning digunakan sebagai tambahan dalam instruksi kelas. Dalam hal ini, tambahannya berupa penyediaan media e-learning, Edmodo sebagai media yang dapat digunakan oleh mahasiswa untuk melakukan diskusi umum. Dari kedua penelitian ini dapat diambil kesimpulan bahwa e-learning ditanggapi positif oleh mahasiswa dan mempunyai pengaruh baik terhadap mahasiswa. Asmuni dan Hidayati (2015) menyatakan bahwa penggunaan Edmodo efektif untuk dipraktikan dalam pembelajaran di perguruan tinggi, bahkan untuk mata kuliah yang bersifat teoritis maupun praktis karena banyak ragam kompetensi yang dapat diperoleh mahasiswa.

Penelitian ini membatasi pada penelitian dari sudut pandang mahasiswa tanpa mengambil data dari dosen pengajar. Pada kajian ini peneliti menggunakan pendekatan yang berbeda, yakni menggunakan pendekatan kualitatif untuk menggali pemahaman yang lebih dalam terkait proses yang terjadi pada e-learning. Kekurangan dari pendekatan kualitatif adalah hasil penelitiannya tidak dapat digeneralisasi pada konteks lainnya namun dapat menguak budaya dari proses e-learning secara penuh.

\section{METODE}

Penelitian dilakukan melalui pendekatan kualitatif. Penelitian kualitatif merupakan pendekatan untuk menggali dan memahami pemaknaan individu atau kelompok pada suatu masalah (Creswell, 2014). Penggunaan pendekatan kualitatif dengan dua alasan. Pertama, penelitian kualitatif sesuai dengan tujuan penelitian yang ingin mendapatkan pemahaman mendalam, hal ini terefleksi pada penggunaan wawancara dan observasi dalam pengumpulan data. Melalui wawancara maka peneliti dapat melakukan pertanyaan lanjutan jika dari jawaban yang diberikan belum tergali informasi yang diinginkan. Kedua, peneliti ingin mendapatkan data sesuai setting partisipan. Melalui observasi peneliti dapat melihat proses secara alami tanpa ada yang tertutupi. Data primer didapatkan melalui observasi partisipan dan wawancara terhadap peserta dalam e-learning melalui kelas virtual Edmodo. Observasi partisipan dilakukan karena peneliti adalah bagian dari peserta dalam kelas virtual. Observasi dilakukan untuk mendapatkan informasi mengenai bagaimana e-learning dilakukan dalam kelas online menggunakan Edmodo. Dimensi penelitian yang ingin didapatkan adalah keaktifan informan dalam kelas dan cara pengungkapan ide dan gagasan dalam kelas virtual. Pengolahan data observasi akan fokus pada kedua hal tersebut. Sementara wawancara 
dilakukan dengan tujuan untuk mendapatkan pemahaman yang mendalam atas fokus penelitian. Wawancara dilakukan secara virtual walaupun sebenarnya dapat dilakukan secara langsung melalui tatap muka. Wawancara secara virtual dipilih dengan tujuan untuk semakin menguatkan proses dalam konteks virtual.

Populasi penelitian adalah 19 mahasiswa. Informan dalam penelitian ini berjumlah 11 mahasiswa. Jumlah informan ini berdasarkan kesediaan mahasiswa untuk diwawancarai. Penggunaan wawancara online melalui Whatsapp digunakan dengan alasan memperkuat situasi virtual yang menjadi objek penelitian. Pada kelas virtual mahasiswa diminta untuk terbiasa mengungkapkan ide dan gagasan melalui teks berbentuk mengetikkan kalimat dalam bentuk tulisan dan bukan suara. Kebiasaan ini juga diungkap oleh dosen B dalam ruang kelas virtual bahwa kelas virtual dapat digunakan untuk melatih mengungkapkan sesuatu melalui tulisan. Kelebihannya bagi peneliti adalah mendapatkan rekaman wawancara secara otomatis. Keterbatasannya adalah terdapat kemungkinan mahasiswa yang tidak terbiasa menjawab pertanyaan melalui teks. Wawancara dilakukan untuk mendapatkan data mengenai pendapat informan terhadap proses pengajaran e-learning. Dimensi penelitian yang ingin diperoleh dari wawancara adalah apakah telah ada pengalaman sebelumnya sebagai partisipan dalam e-learning, kelebihan dan kekurangan dalam e-learning dalam kelas virtual menggunakan Edmodo, dan saran atas e-learning ke depannya. Data yang didapatkan dari wawancara akan diberi kode berdasarkan empat dimensi penelitian tersebut.

\section{HASIL DAN PEMBAHASAN}

Hasil penelitian dipaparkan berdasarkan kategori penelitian, yaitu pengalaman menggunakan e-learning sebelumnya, kelebihan dan kekurangan e-learning secara penuh, proses berjalannya e-learning secara penuh, dan saran atas e-learning secara penuh. Pengalaman menggunakan e-learning sebelumnya dikaji untuk menjawab apakah ada pengaruhnya dalam menjalani e-learning secara penuh. Kelebihan dan kekurangan merupakan persepsi informan atas berjalannya e-learning secara penuh. Dari persepsi ini ditambahkan saran dari informasi atas e-learning secara penuh. Proses berjalannya e-learning secara penuh merupakan proses menggambarkan situasi alami dari e-learning secara penuh.

\subsection{Pengalaman Sebelumnya}

Terdapat empat dari sebelas informan yang menyatakan pernah menggunakan dan terlibat dalam e-learning. Tiga dari keempat informan ini merupakan mahasiswa sarjana Ilmu Perpustakaan UI melalui program pembelajaran jarak jauh Computer Mediated Learning (CML). Ketiga informan ini telah menggunakan CML UI sewaktu kuliah sarjana. CML merupakan suatu perangkat lunak yang dapat digunakan sebagai salah satu metode pembelajaran, berbasis teks dan menggunakan media komputer (Universitas Indonesia, 2008). CML UI dibangun khusus untuk penyelenggaraan mata kuliah Program Dasar Pendidikan Terpadu (PDPT). Fasilitas yang tersedia untuk mahasiswa dalam CML UI adalah fasilitas untuk meng-upload dan men-download materi perkuliahan yang ada, berdiskusi antar-pengguna CML dalam suatu perkuliahan, melihat keaktifan mahasiswa saat berpartisipasi dalam suatu perkuliahan, dan fasilitas untuk mengisi form evaluasi.

Satu informan lagi juga telah menggunakan pula pembelajaran online sewaktu menempuh kuliah sarjana di Universitas Airlangga (Unair). Jika di UI bernama CML UI, maka di Unair bernama Airlangga University E-Learning Application (AULA). AULA 
merupakan aplikasi e-learning website yang dikembangkan sebagai penunjang kegiatan belajar dan mengajar di Unair (Tim E-Learning LP3UA, 2014). Aktivitas di AULA adalah mengakses mata kuliah, mengakses penugasan dari dosen, mengumpulkan tugas, komunikasi antar pengguna secara sinkronus dan asinkronus, mengerjakan ujian online, dan mengakses sumber belajar. Fitur dalam kedua aplikasi e-learning ini merupakan aplikasi yang dibuat khusus oleh organisasi dan memiliki banyak kesesuaian dengan fitur dalam Edmodo. Dengan demikian, keempat informan tersebut telah mempunyai modal awal dibandingkan dengan informan lainnya. Mereka telah mengetahui konsep e-learning sekaligus telah menggunakannya dalam praktek. Sementara tujuh informan mengaku belum pernah menggunakan Edmodo atau sejenisnya dalam proses pembelajaran. Dengan demikian sebagian besar informan adalah pengguna pertama kali e-learning.

\subsection{Kelebihan E-Learning}

Seluruh informan menyatakan e-learning melalui Edmodo baik. Hal tersebut disampaikan oleh tujuh informan, yaitu fleksibel dalam waktu dan tempat. Artinya informan sebagai peserta ajar dan Dosen B sebagai pengajar tidak perlu berada dalam tempat yang sama dan waktu tertentu untuk dapat menyelenggarakan proses belajar mengajar. Diskusi dapat dilakukan meskipun informan sedang di kendaraan dan dalam kondisi lainnya melalui ponsel pintar yang terhubung dengan internet. Informan 1 menyatakan fleksibilitas ini dengan kalimat "membantu kegiatan belajar mengajar jarak jauh”. Informan 1 menyatakan wajar jika e-learning berjalan baik karena “... yang pakai anak UI yang sudah OK banget dan melek teknologi, ga ada gap yang berarti banget karena semuanya di Jakarta atau kota besar". Informan 1 yang sempat bekerja di Perpustakaan Universitas Terbuka (UT) membandingkannya dengan pengalamannya. Menurutnya di UT pengguna e-learning adalah "... rata-rata udah tua-tua, generasi hybrid, dan ada berbagai macam kesenjangan".

Alasan lainnya adalah e-learning secara penuh dengan menggunakan Edmodo mendorong lebih aktif, menyenangkan, canggih, dan simple. Ketiga alasan ini diungkapkan oleh dua informan. Mendorong lebih aktif dapat dilihat dari sisi karena waktu yang lebih panjang dalam diskusi membuat setiap informan dapat mengungkapkan ide dan pendapatnya, termasuk melontarkan pertanyaan jika dalam kelas tatap muka waktu yang tersedia sangat terbatas sehingga tidak memungkinkan semua informan berbicara. Responden 1 dan 5 yang menyatakan dapat mendorong lebih aktif, terlihat jika dalam kelas tatap muka jarang aktif berdiskusi. Dengan demikian mendorong lebih aktif juga dapat dilihat dari sisi bahwa lebih nyaman mengungkapkan pikiran jika tidak melalui tatap muka. Hal ini disadari, terdapat individu yang dapat lebih lepas dalam berbicara ketika tidak dalam posisi tatap muka secara langsung.

Menggunakan Edmodo sangat menyenangkan karena seperti barang mainan baru. Fitur-fitur yang tedapat dalam Edmodo dapat dicoba sendiri oleh informan, seperti adanya penggunaan avatar atau foto pribadi yang mirip dengan media sosial. Menyenangkan juga mengandung arti bahwa secara keseluruhan proses belajar mengajar dengan semua kelebihan yang dirasakan membuat informan menyatakannya sebagai proses yang menyenangkan. Canggih dan simple diungkap oleh informan 7 dan 8 yang merupakan informan yang mempunyai kecenderungan lebih banyak menggunakan teknologi informasi. Canggih dan simple disampaikan dengan maksud bahwa Edmodo mempunyai fitur yang banyak dan dapat digunakan untuk memaksimalkan proses belajar 
mengajar. Walaupun banyak fitur, Edmodo tetap simple dalam arti fitur-fitur tersebut mudah untuk digunakan. Informan 8 menyatakannya dengan kalimat "user friendly sehingga cepat sekali dipelajari". Alasan lain yang disampaikan informan, yakni sebagai berikut.

1) Alat bantu kegiatan belajar mengajar lebih bervariasi. Informan 2 menyatakan alasan ini seperti udara segar karena selama ini pengajaran selalu dilakukan secara tatap muka.

2) Memperkaya pengalaman. Informan 4 mengungkapkan alasan ini merupakan informan yang sebelumnya belum pernah menggunakan aplikasi e-learning seperti Edmodo atau sejenisnya dalam proses belajar mengajar. E-learning dengan menggunakan Edmodo bagi informan 4 dapat memperkaya pengalamannya dalam mendapatkan pengajaran berupa pengajaran virtual.

3) Lebih banyak waktu untuk menelaah topik yang dibicarakan. Alasan ini sebenarnya juga termasuk dalam kategori fleksibilitas dalam hal waktu. Jika dalam proses belajar mengajar tatap muka, waktu diskusi terbatas dalam waktu hanya beberapa jam. Dengan penggunaan Edmodo, diskusi dapat dilakukan kapan saja berdasarkan waktu yang telah ditentukan.

4) Aktif dalam pencarian informasi. Alasan yang diungkap oleh informan 8 ini sebenarnya ambigu, karena baik dalam kelas tatap muka maupun kelas virtual, mahasiswa tetap harus aktif dalam pencarian informasi. Terlebih dalam program magister, mahasiswa dituntut untuk lebih aktif.

5) Menjadi pembelajaran untuk melakukan referensi virtual. Informan 10 lebih melihat sisi praktis dalam pengalamannya menggunakan aplikasi e-learning Edmodo, yaitu menjadi pembelajaran ketika nanti kembali bekerja menjalankan layanan referensi virtual.

6) Interaksi diskusi dan juga materi tersimpan sehingga dapat dilihat kembali. Alasan ini diungkapkan informan 11, yang melihat kelebihan e-learning dari sisi tercatatnya seluruh diskusi secara otomatis. Hal ini sangat berbeda dengan pembelajaran dalam kelas tatap muka dimana jika ingin adanya catatan diskusi, maka diperlukan notulen dan rekaman suara atau rekaman audio visual yang nantinya harus ditranskripkan lagi.

Berdasarkan pembahasan di atas dapat disimpulkan bahwa penggunaan Edmodo dan kelas virtual ditanggapi positif oleh informan, baik yang baru menggunakan aplikasi e-learning maupun yang pernah menggunakan sebelumnya. Dapat disimpulkan bahwa menggunakan Edmodo sebagai media e-learning mempunyai kefleksibelan dalam waktu dan tempat, mendorong lebih aktif dalam berdiskusi, menyenangkan, canggih, dan simple. Karena fleksibel secara waktu memungkinkan lebih banyak waktu untuk menelaah topik diskusi. Penelaahan topik diskusi semakin dalam dengan tersimpannya interaksi diskusi sehingga dapat dilihat kembali. Penggunaan Edmodo merupakan alat bantu kegiatan belajar mengajar agar lebih bervariasi dan memperkaya pengalaman khususnya melalui layanan referensi virtual. Selain alasan fleksibilitas, Edmodo memberikan kesempatan lebih bagi orang yang merasa kesulitan mengungkapkan pendapat dalam kelas tatap muka dan seluruh interaksi dalam kelas terekam dengan baik secara otomatis. 


\subsection{Kekurangan E-Learning}

Meskipun sebagian besar informan menyatakan baik untuk pengajaran melalui e-learning, namun para informan juga mengungkapkan kekurangannya. Terdapat tiga informan, yaitu informan 1, 8, dan 11 yang menyatakan tidak terdapat kesulitan, dan bagi ang merasa sulit hanya butuh penyesuaian dalam penggunaan aplikasi e-learning Edmodo.

\subsubsection{Kekurangan Internal}

Kesulitan penggunaan dapat dikategorikan menjadi kesulitan internal dan eksternal. Kesulitas internal adalah kesulitan terkait faktor yang datang dari pribadi informan. Kesulitan internal yang ditemukan adalah kesulitan dalam penyesuaian waktu dan pemahaman materi. Kedua kesulitan ini masing-masing diungkap oleh dua informan. Kesulitan dalam penyesuaian waktu adalah kesulitan dalam waktu diskusi yang kebetulan dalam kasus ini adalah hari Kamis sampai Sabtu, dan waktu menyelesaikan dan mem-posting kesimpulan adalah hari Minggu. Dalam Satuan Acara Perkuliahan (SAP) yang diposting oleh Dosen B menyatakan "waktu yang dialokasikan untuk diskusi setiap materi adalah dua hari, terhitung sejak tanggal... Seluruh kelas...membuat kesimpulan hasil diskusi...paling lambat hari ke-3 setelah tanggal di atas". Kesulitan pemahaman materi adalah kesulitan terkait kebiasaan dengan kelas tatap muka. Informan 2 yang mengemukakan alasan ini adalah mahasiswa yang baru lulus sarjana dan langsung melanjutkan program magister. Informan 2 menyatakan "bukan termasuk yang mudah paham mengenai materi kelas, terutama materi yang membutuhkan pengetahuan dan pengalaman, sedangkan pengetahuan dan pengalaman saya belum banyak". Informan 2 merasa kesulitan dengan e-learning secara penuh dengan menggunakan Edomodo sebagai kelas virtual.

Kesulitan internal lain adalah tidak dapat download versi mobile. Kesulitan ini dirasakan oleh informan 10. Kesulitan ini terkait dengan penyesuaian waktu. Informan 10 merasakan sulit jika harus berada terus di depan laptop atau komputer untuk memantau kelas virtual. Edmodo sebenarnya mempunyai versi mobile yang beroperasi di ponsel pintar berbasiskan Microsoft, Android, dan Mac. Kebetulan ponsel pintar yang digunakan oleh informan 10 yang sebenarnya berbasiskan Android belum dapat men-download versi mobile Edmodo. Berdasarkan pembahasan di atas dapat disimpulkan bahwa meskipun sebagian informan menyatakan hal positif dengan berbagai alasannya atas e-learning secara penuh dengan Edmodo, namun ada juga informan yang merasakan kekurangan dan kesulitan dalam pengguna Edmodo. Kesulitan terbagi menjadi kesulitan internal dan kesulitan eksternal. Kesulitan internal yang terkait waktu terlihat kontradiksi dengan alasan positifnya e-learning. Di satu sisi informan merasa fleksibel dengan waktunya serta merasakan kesulitan dengan diskusi yang dapat dilakukan di luar jam kerja.

\subsubsection{Kekurangan Eksternal}

Alasan kesulitan eksternal terbanyak adalah jaringan internet. Alasan ini dikemukakan oleh empat informan. Walaupun kampus dan tempat tinggal informan berada di Jakarta dan sekitarnya ternyata jaringan internet masih 
menjadi masalah. Namun, jika melihat aktivitas yang terjadi di kelas, sepertinya masalah jaringan internet tidak terlalu mengganggu. Informan 3 mengatakan bahwa "tidak ada kendala terhadap jaringan internet dalam mengirim tugas kuliah di kampus". Justru alasan seperti sedang berada di luar Jakarta, jaringan internet menjadi alasan yang baik, mengingat infrastruktur di daerah belum sebaik di Jakarta. Dari hasil observasi pada kelas online, terdapat juga mahasiswa yang tidak menjadi informan yang mem-posting, "mohon maaf sedang di luar kota akhir pekan ini, dan mengalami kesulitan sinyal...”.

Dosen merasakan faktor jaringan internet ini. Saat menanggapi akhir diskusi pertama, Dosen B menyatakan "seminggu kemarin berada di luar kota dan akses internet sulit...". Selain itu, karena waktu yang disediakan sebenarnya menjadi lebih banyak maka masalah jaringan internet tidak terlalu mengganggu. Kesulitan eksternal lainnya, yaitu: (1) terjadi ketergantungan atas alat elektronik. Sistem virtual berupa e-learning secara penuh jelas sangat membutuhkan teknologi untuk mengaksesnya. Tanpa adanya teknologi tersebut, informan tidak akan dapat hadir dalam kelas virtual. Kelas virtual membuat ketergantungan partisipan kepada alat elektronik; dan (2) Ketika melakukan submit tugas akhir, aplikasinya terlihat seperti loading terus. Hal ini menyebabkan informan bertanya-tanya apakah tugas sudah terunggah secara penuh.

Kesulitan eksternal di atas merupakan kesulitan eksternal pada faktor teknologi. Selain faktor teknologi, terdapat juga kesulitan eksternal yang merupakan faktor manusia, yaitu tidak adanya kontrol dalam diskusi yang terjadi di kelas virtual. Hal ini dirasakan oleh dua informan. Informan 4 menyatakan "interaksi dengan dosen jadi berkurang dan terkesan dilepas begitu saja diskusinya". Hal ini menyebabkan pembahasan dalam diskusi melebar bahkan kurang termaknai. Dosen B sebenarnya sudah memberikan point penting dalam diskusi setiap akhir waktu diskusi. Menurut informan 5 “...inginnya pengajar ikut terlibat kasih komentar juga pada forum diskusi, jadi bukan komentar di akhir sesi aja". Dalam awal e-learning secara penuh, Dosen B sebenarnya terlihat sangat aktif membalas seluruh posting pengenalan dari informan dengan pernyataan "selamat datang dan bergabung di kelas virtual kita...". Respon yang sama juga dilakukan Dosen B dengan selalu merespon posting pengumpulan kesimpulan dengan pernyataan "noted". Setelah perkenalan, dosen mem-posting pembuka kelas "selamat bergabung di grup edmodo kita...". Dosen B melanjutkan dengan mem-posting SAP mata kuliah AB khusus untuk yang diajarnya. Dosen B juga mem-posting buku elektronik yang digunakan untuk bahan diskusi. Di akhir sesi, Dosen B menutup kelas virtual layaknya dalam pertemuan tatap muka secara langsung.

Dosen B juga menjawab pertanyaan yang diajukan oleh informan melalui posting. Contohnya adalah informan 8 yang bertanya "bagaimana jika dateline ini dimajukan atau dimundurkan untuk pengumpulan kesimpulan mengingat Sabtu Minggu adalah weekend". Usulan ini dijawab bahwa belum dapat diterima. Hal ini menunjukkan Dosen B memantau penuh perkembangan kelas virtual karena pertanyaan yang diajukan melalui posting tidak akan terlihat karena pertanyaan tersebut berada di ruang kelas, tidak seperti mengirimkan pesan langsung ke dosen. Hal lain yang menunjukkan pemantauan oleh dosen adalah 
postingan yang menyatakan "...diskusi dengan aktif walaupun tidak semua mahasiswa berpartisipasi dalam diksusi". Termasuk ada mahasiswa yang tidak mengumpulkan kesimpulan. Kedua hal ini, menjawab pertanyaan di kelas dan mengetahui mahasiswa yang tidak berpartisipasi dalam diskusi dan mengumpulkan tugas, merupakan bentuk aktif Dosen B dalam kelas virtual. Dosen B selalu memberikan komentar di akhir diskusi. Dari lima tema diskusi, hanya pada diskusi pertama Dosen B hanya menanggapi namun belum dapat memberi komentar. Dosen B memberikan komentar bahasan diskusi tema pertama pada akhir bahasan tema diskusi kedua. Komentar atas bahasan diskusi yang perlu digarisbawahi merupakan bukti keaktifan Dosen B untuk mendengarkan seluruh bahasan diskusi. Kelebihannya adalah seperti yang diungkap oleh informan 11 bahwa seluruh aktivitas interaksi dalam kelas terekam secara otomatis dengan baik. Hal ini dapat memudahkan dosen untuk melihat kembali jalannya diskusi.

Berdasarkan pembahasan di atas dapat disimpulkan bahwa untuk kesulitan eksternal yang paling banyak dikemukakan adalah jaringan internet. Kesulitan ini tidak menjadi alasan yang membuat $e$-learning tidak berjalan dengan baik mengingat waktunya yang fleksibel. Kesulitan eksternal lain adalah adanya ketergantungan atas alat elektronik yang memang merupakan konsekuensi atas e-learning, termasuk adanya kemungkinan error dalam penggunaan aplikasi. Untuk kesulitan eksternal terkait faktor manusia (dosen), yaitu perasaan tidak ada interaksi yang erat dengan dosen pengajar yang menimbulkan keinginan adanya campuran antara e-learning dan kelas tatap muka secara langsung. Dosen mampu menjalankan e-learning sesuai atau sama halnya dosen lainnya ketika melakukan pengajaran dalam kelas tatap muka. Keinginan untuk tetap ada tatap muka langsung lebih dikarenakan adanya posisi awal atas pemberian label bahwa dirinya tradisional yang belum terbiasa dengan e-learning. Pola pikir ini sekaligus menjadi faktor kesulitan internal.

\subsection{Jalannya E-Learning}

Kelas virtual menggunakan Edmodo dilakukan observasi dalam prosesnya. Dalam lima bahasan yang dipresentasikan, terlihat diskusi sangat ramai. Ramainya diskusi juga dirasakan oleh Dosen B ketika melakukan komentar di setiap akhir diskusi. Dosen B menyatakan "diskusi berlangsung seru, seluruh kelas berpartisipasi aktif, dan kelas aktif berpartisipasi”. Diskusi ramai ini berdasarkan pada fakta bahwa seluruh informan terlibat aktif dalam setiap bahasan diskusi minimal satu kali ketika menjadi bukan anggota kelompok yang presentasi, yaitu bertanya. Kesempatan bertanya menjadi lebih panjang secara waktu karena tidak terbatas seperti pada kelas tatap muka. Hal ini juga didorong oleh Dosen B agar para mahasiswanya berperan aktif. Hal ini diambil secara minimal dengan sekali bertanya pada setiap bahasan di luar bahasan kelompoknya. Bagi informan yang sedang melakukan presentasi, terlihat lebih aktif menjawab.

Diskusi juga dinilai ramai karena terkadang untuk satu pertanyaan atau tanggapan terlihat beberapa kali mendapatkan tanggapan atau mendapatkan pertanyaan yang lebih mendalam. Contohnya dalam diskusi tema pertama, informan 8 meminta penjelasan yang lebih lanjut atas penjelasan yang belum terjawab "maaf sebelumnya, saya belum menemukan jawaban yang memuaskan saya...”. Informan 8 ingin menambahkan dari jawaban kelompok penyaji dalam diskusi tema kedua dengan 
pernyataan "saya mau menambahkan tentang jawaban...". Tanggapan dan pertanyaan yang lebih mendalam seperti ini dapat ditemukan beberapa kali dalam diskusi sehinggga membuat diskusi terasa hidup dan seru.

Tabel 1. Jumlah Posting dalam Kelas Virtual

\begin{tabular}{|c|c|c|c|c|c|c|c|c|c|c|c|}
\hline Keterangan & $\begin{array}{c}\text { Inf } \\
\mathbf{1}\end{array}$ & $\begin{array}{c}\text { Inf } \\
\mathbf{2}\end{array}$ & $\begin{array}{c}\text { Inf } \\
\mathbf{3}\end{array}$ & $\begin{array}{c}\text { Inf } \\
\mathbf{4}\end{array}$ & $\begin{array}{c}\text { Inf } \\
\mathbf{5}\end{array}$ & $\begin{array}{c}\text { Inf } \\
\mathbf{6}\end{array}$ & $\begin{array}{c}\text { Inf } \\
\mathbf{7}\end{array}$ & $\begin{array}{c}\text { Inf } \\
\mathbf{8}\end{array}$ & $\begin{array}{c}\text { Inf } \\
\mathbf{9}\end{array}$ & $\begin{array}{c}\text { Inf } \\
\mathbf{1 0}\end{array}$ & $\begin{array}{c}\text { Inf } \\
\mathbf{1 1}\end{array}$ \\
\hline $\begin{array}{c}\text { Jumlah } \\
\text { Posting }\end{array}$ & 28 & 25 & 39 & 32 & 32 & 24 & 55 & 40 & 27 & 27 & 37 \\
\hline
\end{tabular}

Diskusi sebenarnya dapat dilakukan pada tingkatan kelas maupun pada kelompok presentasi. Jumlah posting di atas merupakan gabungan dari kedua tingkatan tersebut. Namun diskusi dalam tingkatan kelompok presentasi tidak dilakukan observasi. Terlihat informan 7 melakukan posting terbanyak sejumlah 55 kali dan informan 6 melakukan posting paling sedikit, yaitu 24 kali. Jika dibuat rata-rata posting kelas, informan 6 berada di bawah rata-rata posting kelas. Rata-rata posting kelas adalah 33 posting. Dengan demikian diketahui delapan informan yang berada pada posisi di bawah rata-rata posting kelas.

Berdasarkan data di atas dapat disimpulkan ternyata kelas virtual mampu membuat kelas lebih aktif walaupun secara rata-rata sebagian besar masih di bawah rata-rata posting kelas.

Tabel 2. Kualitas Posting dalam Kelas Virtual

\begin{tabular}{|c|c|c|c|c|c|c|c|c|c|c|c|}
\hline $\begin{array}{c}\text { Jumlah } \\
\text { Posting }\end{array}$ & $\begin{array}{c}\text { Inf } \\
\mathbf{1}\end{array}$ & $\begin{array}{c}\text { Inf } \\
\mathbf{2}\end{array}$ & $\begin{array}{c}\text { Inf } \\
\mathbf{3}\end{array}$ & $\begin{array}{c}\text { Inf } \\
\mathbf{4}\end{array}$ & $\begin{array}{c}\text { Inf } \\
\mathbf{5}\end{array}$ & $\begin{array}{c}\text { Inf } \\
\mathbf{6}\end{array}$ & $\begin{array}{c}\text { Inf } \\
\mathbf{7}\end{array}$ & $\begin{array}{c}\text { Inf } \\
\mathbf{8}\end{array}$ & $\begin{array}{c}\text { Inf } \\
\mathbf{9}\end{array}$ & $\begin{array}{c}\text { Inf } \\
\mathbf{1 0}\end{array}$ & $\begin{array}{c}\text { Inf } \\
\mathbf{1 1}\end{array}$ \\
\hline Diskusi 1 & 2 & 1 & 4 & 2 & 2 & 1 & 4 & 3 & 1 & 8 & 1 \\
\hline Diskusi 2 & 1 & 1 & 0 & 2 & 3 & 1 & 4 & 1 & 1 & 2 & 8 \\
\hline Diskusi 3 & 1 & 2 & 1 & 5 & 1 & 1 & 15 & 2 & 5 & 1 & 1 \\
\hline Diskusi 4 & 7 & 1 & 13 & 1 & 1 & 9 & 1 & 10 & 1 & 3 & 1 \\
\hline Diskusi 5 & 1 & 5 & 6 & 1 & 10 & 1 & 3 & 2 & 1 & 1 & 1 \\
\hline Total & $\mathbf{1 2}$ & $\mathbf{1 0}$ & $\mathbf{2 4}$ & $\mathbf{1 1}$ & $\mathbf{1 7}$ & $\mathbf{1 3}$ & $\mathbf{2 7}$ & $\mathbf{1 8}$ & $\mathbf{9}$ & $\mathbf{1 5}$ & $\mathbf{1 2}$ \\
\hline
\end{tabular}

Apabila dilihat isi dari posting terlihat bahwa rata-rata melakukan posting yang berkualitas. Berkualitas artinya posting sesuai materi diskusi dan bukan posting sebatas mengucapkan "terima kasih atas jawabannya" atau "saya sepakat dengan A". Tabel 2 di atas memperlihatkan jumlah posting yang dinilai berkualitas dalam diskusi di kelas bukan diskusi dalam kelompok bahasan.

Hal yang menarik adalah terlihat adanya sikap menggugurkan kewajiban dalam setiap diskusi. Dosen B mengharapkan agar setiap mahasiswa aktif dalam setiap diskusi. Harapan ini diterjemahkan oleh informan dengan mengambil partisipasi minimal saja. Dapat dilihat dengan banyaknya jumlah postingan yang hanya berjumlah satu posting. Umumnya postingan pertama adalah berupa pertanyaan. Postingan kedua adalah berupa ucapan terima kasih sudah menjawab. Terkadang bahkan mahasiswa hanya melemparkan pertanyaan saja. Selanjutnya mahasiswa tersebut tidak terlihat muncul lagi dalam diskusi. Keunggulan dalam masalah waktu dalam kelas virtual menjadi bumerang bagi informan. Jika sebelumnya dalam kelas tatap muka tidak semua mahasiswa dapat kesempatan berbicara dalam satu kali diskusi karena keterbasan waktu maka dengan waktu yang 
sangat panjang dan fleksibel menuntut mahasiswa untuk berpartisipasi minimal dengan menyampaikan pertanyaan.

Berdasarkan pembahasan di atas dapat disimpulkan bahwa jalannya diskusi berlangsung dengan ramai dan berhasil membuat mahasiswa berkontribusi secara minimal. Ramai jika dilihat jumlah balasan dalam masing-masing tema diskusi dan menambahkan jawaban/pertanyaan kedua yang diajukan untuk diskusi lebih mendalam.

\subsection{Saran E-Learning}

Proses belajar mengajar menggunakan e-learning secara penuh dalam kelas $\mathrm{AB}$ selama setengah semester mempunyai kelebihan dan kekurangan. Proses belajar mengajar menggunakan e-learning secara penuh juga telah digambarkan. Gambaran proses tersebut menangkap adanya kelebihan dan kekurangan. Untuk itu diperlukan adanya saran untuk perbaikan proses belajar mengajar menggunakan e-learning secara penuh. Saran dapat dibagi menjadi dua, yaitu terhadap fitur e-learning dan proses belajar mengajar.

Saran terhadap fitur e-learning dikemukakan oleh dua informan, yaitu perlu adanya fitur dalam diskusi yang dapat mengirimkan gambar dan penambahan fitur video conference. Saran fitur yang dapat mengirimkan gambar pendukung. Sebenarnya fitur mengirimkan gambar terdapat dalam Edmodo. Untuk melakukan posting dengan melampirkan berbagai jenis file, termasuk gambar. Namun fitur tersebut hanya ada pada postingan baru. Jika melakukan reply (balas) tidak dapat dilakukan pelampiran berbagai jenis file, artinya tidak dapat mengirimkan gambar. Saran lain adalah tersedianya fitur video conference. Penggunaan teks dalam diskusi memang membutuhkan konsentrasi. Diskusi berbentuk teks tertulis seperti membaca buku yang hanya terdapat tulisan saja. Kecenderungan manusia adalah menatap wajah yang sedang diajak komunikasi. Atas dasar kecenderungan ini, komunikasi virtual menciptakan video call, jika antar-individu dan video conference, jika pelaku komunikasi lebih dari dua partisipan. Fitur ini memang tidak terdapat dalam Edmodo. Namun pengguna Edmodo dapat mengunggah video melalui posting yang dapat digunakan sebagai alternatif melihat lawan bicara. Saran penambahan fitur video conference ini diberikan oleh informan 3. Informan 3 dalam masalah kesulitan penggunaan e-learning menyatakan merasakan kesulitan dalam fasilitas internet. Saran ini sepertinya bertentangan dengan kesulitan yang dialaminya. Dengan penggunaan video conference jelas lebih membutuhkan fasilitas internet yang kuat.

Saran selanjutnya adalah saran yang terkait dengan proses. Saran pertama adalah dosen yang lebih aktif dalam proses belajar mengajar menggunakan e-learning secara penuh. Saran ini diberikan oleh lima informan. Informan 1 menyatakan "mungkin dosen dapat lebih aktif memberikan materi". Hal yang senada diungkapkan oleh informan 6 dengan menyatakan "mungkin dosen dan mahasiswa lebih saling aktif kayak pertemuan tatap muka biasanya". Sementara tiga informan lagi lebih khusus terkait aktif dalam diskusi "inginnya pengajar ikut terlibat kasih komentar juga pada forum diskusi, bukan komentar di akhir sesi saja"; "dosen mampu mengikuti dan memantau kegiatan belajar mengajar sehingga pembahasan tidak terlalu melebar"; dan "dosen juga berpartisipasi dalam diskusi sehingga bahasan tidak melebar ke mana-mana".

Saran lain menyangkut faktor dosen, yaitu perlunya aturan main yang lebih jelas, mulai dari waktu diskusi dan proses diskusi. Informan 10 merasakan bahwa bahasan diskusi terkadang terlalu melebar sehingga mengusulkan "tiap diskusi harus ada 
moderatornya". Pada saran pertama, informan memposisikan dosen yang harusnya berfungsi sebagai moderator. Sementara informan 10 tidak secara eksplisit menyebutkan moderator sebaiknya dilakukan oleh dosen. Saran e-learning terkait dosen, sebenarnya sudah dapat dijawab melalui SAP. Terkait aturan main, Dosen B sudah menjelaskan dengan memberikan SAP yang sudah menjelaskan semuanya, mulai dari jadwal perkuliahan, tugas dalam kuliah, aturan mengenai diskusi dan pengumpulan kesimpulan diskusi. Aturan mengenai diskusi termasuk waktu yang telah ditetapkan. Di ruang kelas virtual, dosen juga kembali menegaskan aturan main tersebut baik ketika dalam rangka mengingatkan dan menjawab pertanyaan terkait aturan main.

Terkait moderator, dalam SAP tersirat bahwa "kelompok PJ minggu dsb harus terus aktif memantau jalannya diskusi...". Hal ini mengindikasikan agar moderator dalam diskusi terletak pada kelompok yang menyajikan presentasi bahasan diskusi. Dalam setiap tanggapan dan komentar di akhir diskusi, dosen B juga menegaskan hal ini kembali. Misalnya, pada akhir diskusi tema pertama, dosen B menyatakan “...diskusi yang dipandu kelompok 1 dapat memberikan pengetahuan...". Dengan memberikan peran moderator ini, maka setiap kelompok penyaji mempunyai hak untuk mengatur diskusi termasuk jika pembahasan dirasakan melebar. Selain itu, menurut dosen B, dalam memberikan komentar hasil diskusi juga menyatakan "tidak ada yang terlalu menyimpang jauh atau perlu diluruskan".

Penegasan secara implisit ini pun juga dapat menjadi legitimasi dosen untuk tidak ambil bagian pada waktu diskusi berjalan dan cukup memberikan komentar di akhir diskusi. Seperti halnya dalam kelas tatap muka, pengajar membiarkan diskusi kelas berjalan apa adanya tanpa intervensi langsung. Pengajar hanya mencatat hal-hal penting yang perlu dibicarakan dan dikomentari atau perlu diluruskan jika perlu. Pemberian komentar di dalam diskusi dapat membuyarkan jalannya diskusi. Pertanyaan yang seharusnya diberikan kepada kelompok penyaji tanpa disadari akan berpindah arah ditanyakan kepada pengajar.

Hal selanjutnya terkait dengan waktu diskusi "jangan dibuat terlalu lama, karena agak membebani dan membuat peserta kurang fokus". Hal senada juga diungkapkan oleh informan 7 yang menyatakan, "pelaksanaan diskusi dan pengerjaan tugas harus seiring waktu lazimnya perkuliahan”. Informan 4 mengungkapkan perlu adanya aturan main yang jelas. Dalam kelas tatap muka sebenarnya fungsi moderator dalam diskusi selain dilakukan langsung oleh dosen, fungsi tersebut juga dapat dipindahkan ke mahasiswa atas permintaan dosen. Seperti yang telah diungkap dalam kelemahan e-learning, usulan untuk memajukan atau memundurkan jadwal diskusi dan pengumpulan kesimpulan oleh informan 8 , dosen belum menerima usulan tersebut. Usulan ini sebenarnya didukung oleh informan 4 dan 9 yang membalas usulan tersebut dan menyatakan setuju. Sepertinya dosen ingin memberikan pengalaman yang penuh juga atas penerapan e-learning secara penuh. Seperti yang diungkap dalam postingannya di kelas virtual "mudah-mudahan materi dan diskusi yang dipandu, memberikan pengetahuan dan pembelajaran yang menyenangkan bagi seluruh kelas". Dalam postingan pembuka, Dosen B juga menyatakan "semoga grup ini memberikan manfaat yang banyak dalam peningkatan wawasan dan pengetahuan kita". Jawaban langsung dari pertanyaan informan 8 tersebut, "mudah-mudahan kelak akan jadi kenangan, manisnya perjuangan menempuh studi lanjut di tengah beban amanah yang juga harus kita tunaikan...". Terlihat Dosen B sering menggunakan kata pengalaman yang 
menyenangkan. Hal ini sejalan dengan salah satu alasan kebaikan dari e-learning yang diungkap informan, yaitu pengalaman menyenangkan dan pengalaman nantinya melalukan layanan referensi virtual dalam kerja sehari-hari. Saran lain terkait proses ini perlu adanya elaborasi antara kelas virtual dan tatap muka. Saran ini dikemukakan oleh empat informan. Dua informan menyatakan pertemuan tatap muka diperlukan minimal pada awal pertemuan. Saran ini menyiratkan bahwa informan belum siap dengan kondisi virtual secara utuh, informan belum sepenuhnya setuju dengan proses e-learning secara penuh dalam kelas virtual. Hal ini dinyatakan secara langsung oleh informan 6 yang termasuk memberikan saran terkait tatap muka.

Informan 6 menyatakan "terbiasa tradisional, jadi belum terbiasa e-learning". Di kalimat lain, informan menyatakan, "terbiasa kelas tradisional jadi ada yang kurang aja kalau e-learning". Informan 6 adalah informan yang menyatakan sudah pernah menggunakan e-learning Edmodo dalam kuliah sarjananya. Dua pengalaman yang telah dilaluinya tidak membuat dirinya menyenangi proses e-learning. Hal ini ditambah dengan pernyataan eksplisit atas dirinya yang terbiasa tradisional. Pernyataan ini dapat membentuk dirinya dan membuat benteng atas ketidakbiasaannya dengan lingkungan e-learning.

Berdasarkan pembahasan di atas dapat disimpulkan bahwa saran yang diberikan terkait e-learning secara penuh melalui penggunaan Edmodo sebagai kelas virtual adalah saran teknis berupa fitur memasukkan gambar dan fitur video conference, saran proses yang terkait dosen berupa penggunaan model tatap muka juga dalam e-learning. Sementara aturan main yang jelas dan tuntutan dosen lebih aktif dalam penelitian ini kurang tepat karena temuan menunjukkan aturan main sudah jelas dan porsi dosen sudah dilakukan dengan baik oleh Dosen B.

\section{KESIMPULAN}

Pengalaman mahasiswa telah menggunakan e-learning sebelum mengikuti mata kuliah $\mathrm{AB}$ bukan satu-satunya faktor yang mempengaruhi persepsi mengikuti e-learning secara penuh dalam kelas virtual pada mata kuliah $\mathrm{AB}$ tidak mempengaruhi persepsi proses e-learning. Hal ini tergambar dengan adanya mahasiswa yang telah mempunyai pengalaman mengikuti e-learning sebelumnya tetap lebih menyukai kelas konvensional melalui tatap muka. Pengalaman hanya mempengaruhi faktor teknis dalam mengikuti e-learning secara penuh. Secara umum e-learning secara penuh menggunakan Edmodo sebagai kelas virtual dalam pengajaran selama setengah semester untuk mata kuliah $\mathrm{AB}$ dengan dosen $\mathrm{B}$ mendapat tanggapan positif dari mahasiswanya baik yang baru pertama kali menggunakan aplikasi e-learning maupun yang sudah pernah menggunakan sebelumnya. Edmodo sebagai kelas virtual memberikan kefleksibelan dalam waktu dan tempat, mendorong lebih aktif dalam berdiskusi, memungkinkan lebih banyak waktu untuk menelaah topik diskusi, bersifat menyenangkan, bervariasi, dan memperkaya pengalaman, serta Edmodonya sendiri canggih dan sederhana. Dalam e-learning ini menuntut mahasiswa aktif dalam pencarian informasi seperti halnya pembelajaran melalui tatap muka langsung. Dengan demikian, e-learning secara konsep dan praktis mempunyai keuntungan dalam proses belajar mengajar.

Walaupun menyatakan hal positif tetap ada kekurangan yang dirasakan mahasiswa yang bersifat internal berupa waktu yang dilakukan di luar jam kerja dan yang bersifat eksternal berupa jaringan internet, ketergantungan atas alat elektronik, dan faktor dosen. Jaringan internet seharusnya tidak menjadi kesulitan bagi mahasiswa UI. Sementara 
ketergantungan pada alat elektronik merupakan konsekuensi dari penerapan e-learning secara penuh. Kekurangan yang dirasa oleh mahasiswa adalah dosen yang seharusnya lebih aktif dan mahasiswa yang menilai tetap perlu ada tatap muka minimal di awal pengajaran. Hasilnya menunjukkan bahwa dosen sudah berada dalam porsinya sebagai pengajar. Keinginan untuk ada tatap muka dikarenakan pembentukan persepsi diri sendiri yang masih terbiasa konvensional (tatap muka langsung). Pola pikir ini sekaligus menjadi faktor kesulitan internal.

E-learning secara penuh dengan menggunakan Edmodo sebagai kelas virtual menunjukkan interaksi kelas dan diskusi berlangsung dengan ramai dan berhasil membuat mahasiswa berkontribusi secara minimal jika melihat kuantitas posting walaupun masih sebagian besar masih berada di bawah rata-rata posting kelas, kuantitas balasan dalam masing-masing tema diskusi, dan tanggapan yang menambahkan jawaban dan pertanyaan kedua yang diajukan untuk lebih mendalamkan diskusi. Secara kualitas, kontribusi yang minimal mengindikasikan sikap menggugurkan kewajiban dengan minimal sekali bertanya dalam setiap diskusi. Setelah menjalani e-learning, mahasiswa memberikan masukan dalam hal teknis berupa fitur memasukkan gambar dan fitur video conference dalam aplikasi e-learning, saran dalam hal proses berupa penggunaan model tatap muka juga dalam e-learning, penetapan aturan main dan meminta dosen lebih aktif.

Penulis menyarankan bahwa e-learning dapat digunakan secara penuh dalam proses belajar mengajar. Agar e-learning secara penuh berhasil diperlukan persyaratan awal berupa adanya aplikasi dengan fitur Edmodo, jaringan internet yang kuat, dan teknologi untuk mengakses aplikasi e-learning. Selain itu, dosen sebagai subjek harus mampu membuat aturan main yang jelas dan harus aktif dalam proses pengajaran. Mahasiswa sebagai objek harus terbiasa untuk mengemukakan pendapat melalui tulisan dan terbiasa untuk tidak sekedar menggugurkan kewajiban dalam melakukan diskusi sebagai pendalaman materi yang dipelajari. Penelitian ke depan dapat dilakukan dengan mengambil data dari dosen pengajar.

\section{DAFTAR PUSTAKA}

Asmuni dan Hidayati, W.S. 2015. Pengaruh Penggunaan Media Jejaring Sosial Edmodo Terhadap Partisipasi Mahasiswa dalam Diskusi Kelas pada Materi Ajar Teoretis dan Praktis. Prosiding Seminar Nasional Hasil Penelitian Pendidikan dan Pembelajaran STKIP PGRI Jombang, 25-26 April.

Creswell, J.W. 2014. Research Design: Qualitative, Quantitative, and Mixed Methods Approaches. Los Angeles: Sage Publications.

Gedera, D. P. 2014. Students Experiences of Learning in A Virtual Classroom. International Journal of Education \& Development Using Information \& Communication Technology, 10 (4), 93-101.

Hogan, R. 2011. eLearning: a Survival Strategy for Developing Countries. Social and Economic Studies, 60(3/4), 127-150.

Marzal, J. 2014. Studi Penggunaan Jejaring Sosial Edmodo sebagai Media E-Learning oleh Dosen Senior yang tidak Terbiasa Bekerja dengan Komputer. Edumatica, Vol.04 No. 01, April.

Tim E-Learning LP3UA. 2014. "Pengenalan AULA: Airlangga University e-Learning Application". (http://slideplayer.info/slide/3652393/, diakses 29 Maret 2016).

Universitas Indonesia. 2008. "Materi Computer Mediated Learning: Untuk Kegiatan Orienstasi 
Belajar

Mahasiswa

2008.

(http://www.clr.ui.ac.id/wp-content/uploads/2008/08/materi-cml2.pdf, diakses 29 Maret 2016). 